\title{
Involvement of cerebrovascular abnormalities in the pathogenesis and progression of Alzheimer's disease: an adrenergic approach
}

\author{
Song $\mathbf{L i}^{1,2, *}$, Che Wang ${ }^{3, *}$, Zhen Wang ${ }^{4}$, Jun Tan ${ }^{5}$ \\ ${ }^{1}$ Liaoning Provincial Center for Clinical Research on Neurological Diseases, The First Affiliated Hospital, Dalian \\ Medical University, Dalian 116021, China \\ ${ }^{2}$ Liaoning Provincial Key Laboratory for Research on the Pathogenic Mechanisms of Neurological Diseases, The \\ First Affiliated Hospital, Dalian Medical University, Dalian 116021, China \\ ${ }^{3}$ Department of Pharmaceutical Chemistry, School of Chemistry and Chemical Engineering, Liaoning Normal \\ University, Dalian 116029, China \\ ${ }^{4}$ Department of Neurology, The First Affiliated Hospital of Wenzhou Medical University, Wenzhou 325000, China \\ ${ }^{5}$ Key Laboratory of Endemic and Ethnic Diseases, Guizhou Medical University, Guiyang 550004, China \\ ${ }^{*}$ Equal contribution
}

Correspondence to: Song Li, Jun Tan; email: lisong@dmu.edu.cn, jitan@gmc.edu.cn Keywords: Alzheimer's disease, adrenergic receptors, $\beta$-amyloid, cerebrovascular, tau

Received: May 24, 2021

Accepted: August 17, 2021

Published: September 3, 2021

Copyright: (C) $2021 \mathrm{Li}$ et al. This is an open access article distributed under the terms of the Creative Commons Attribution License (CC BY 3.0), which permits unrestricted use, distribution, and reproduction in any medium, provided the original author and source are credited.

\section{ABSTRACT}

Alzheimer's disease (AD), as the most common neurodegenerative disease in elder population, is pathologically characterized by $\beta$-amyloid $(A \beta)$ plaques, neurofibrillary tangles composed of highly-phosphorylated tau protein and consequently progressive neurodegeneration. However, both $A \beta$ and tau fails to cover the whole pathological process of $A D$, and most of the $A \beta$ - or tau-based therapeutic strategies are all failed. Increasing lines of evidence from both clinical and preclinical studies have indicated that age-related cerebrovascular dysfunctions, including the changes in cerebrovascular microstructure, blood-brain barrier integrity, cerebrovascular reactivity and cerebral blood flow, accompany or even precede the development of AD-like pathologies. These findings may raise the possibility that cerebrovascular changes are likely pathogenic contributors to the onset and progression of AD. In this review, we provide an appraisal of the cerebrovascular alterations in $A D$ and the relationship to cognitive impairment and $A D$ pathologies. Moreover, the adrenergic mechanisms leading to cerebrovascular and $A D$ pathologies were further discussed. The contributions of early cerebrovascular factors, especially through adrenergic mechanisms, should be considered and treasured in the diagnostic, preventative, and therapeutic approaches to address AD.

\section{INTRODUCTION}

Alzheimer's disease (AD) is the most common form of neurodegenerative disease in elder population worldwide. It is estimated that, by 2060, the number of AD patients in Americans age 65 and older may increase to 13.8 million from 6.2 million today [1]. AD is clinically characterized as cognitive decline and psychiatric manifestations. The pathological hallmarks of AD brain are the accumulation of extracellular $\beta$-amyloid $(\mathrm{A} \beta)$ (senile plaques) and the intracellular twisted strands of the hyper-phosphorylated tau protein (neurofibrillary tangles). These changes in the brain are accompanied by the neuronal damage. $\mathrm{AD}$ is a progressive neurodegenerative disorder that can start decades before the appearance of clinical symptoms. Although several pathological mechanisms of AD have been identified, no satisfactorily effective therapeutics has been developed. 
Recently, cerebrovascular dysfunctions, as a possible cause in the development and progression of sporadic $\mathrm{AD}$, have gained increasing attention [2-4]. Increasing evidence has indicated the involvement of various alterations in cerebrovascular structure or functions, such as the cerebrovascular microstructure, blood-brain barrier (BBB) integrity, composition of neurovascular unit, cerebrovascular reactivity and cerebral blood flow $(\mathrm{CBF})$, in $\mathrm{AD}$ pathophysiology and cognitive defects [5, 6]. Recent findings further highlighted the prevalence of cerebrovascular disorders in Down syndrome patients and added to a growing body of evidence implicating cerebrovascular abnormalities as a core feature of $\mathrm{AD}$ rather than a simple comorbidity [7]. Moreover, adrenergic system, including $\alpha / \beta$ adrenergic receptors and their downstream molecular signaling process, might serve as the key approach to modulate these cerebrovascular abnormalities and progressive neurodegeneration [8]. In this review, we summarized the interplay between cerebrovascular function and $\mathrm{AD}$ pathologies in both $\mathrm{AD}$ animal models and $\mathrm{AD}$ patients. Moreover, the underlying adrenergic mechanisms were further discussed to explore potential targets for future $\mathrm{AD}$ diagnosis and therapy.

\section{Cerebrovascular dysfunctions in AD}

\section{Abnormal cerebrovascular microstructure in AD}

While a so-called ATN classification system of AD composed of $\mathrm{A} \beta[\mathrm{A}]$ and tau $[\mathrm{T}]$ pathologies as well as neurodegeneration $[\mathrm{N}]$ have been established $[9,10]$, this system fails to present a clear causality and acknowledges an uncertain relationship between $\mathrm{AD}$ pathologies and $\mathrm{AD}$ symptoms. Considering the multifactorial feature of $\mathrm{AD}$ with complicate pathologies and manifestations, other factors, such as chronic and early cerebrovascular alterations, may contribute to the disease development and progression (Figure 1).

In 1991, microvessels in the brains of patients with AD were firstly observed by the scanning electron microscopy. Compared with control brain, obvious changes were observed in $\mathrm{AD}$ brains, including the focal constriction in terminal arterioles, irregular shape of smooth muscle cells, and the irregular abluminal surface and irregular constriction and dilatation of capillaries [11]. Microvascular ultrastructural changes in brain have also been reported to be prior to the onset of cognitive impairment in APP/PS1 AD model mice at 4 to 5 months of age [12]. Interestingly, despite the alterations of vasculature in brain, microvascular pathologies were also found in peripheral in AD [13]. At day 70 following femoral ligation, APP/PS1 mice showed significant decreases in cutaneous blood flow, collateral recruitment, capillary density and arteriole density in hind limbs compared to control wild-type littermates.

\section{Abnormal cerebral blood flow in AD}

In the gray matter of $\mathrm{AD}$ brain, $\mathrm{CBF}$ can be reduced by more than $40 \%$, with the largest decrease in the right supramarginal gyrus and the smallest in the right

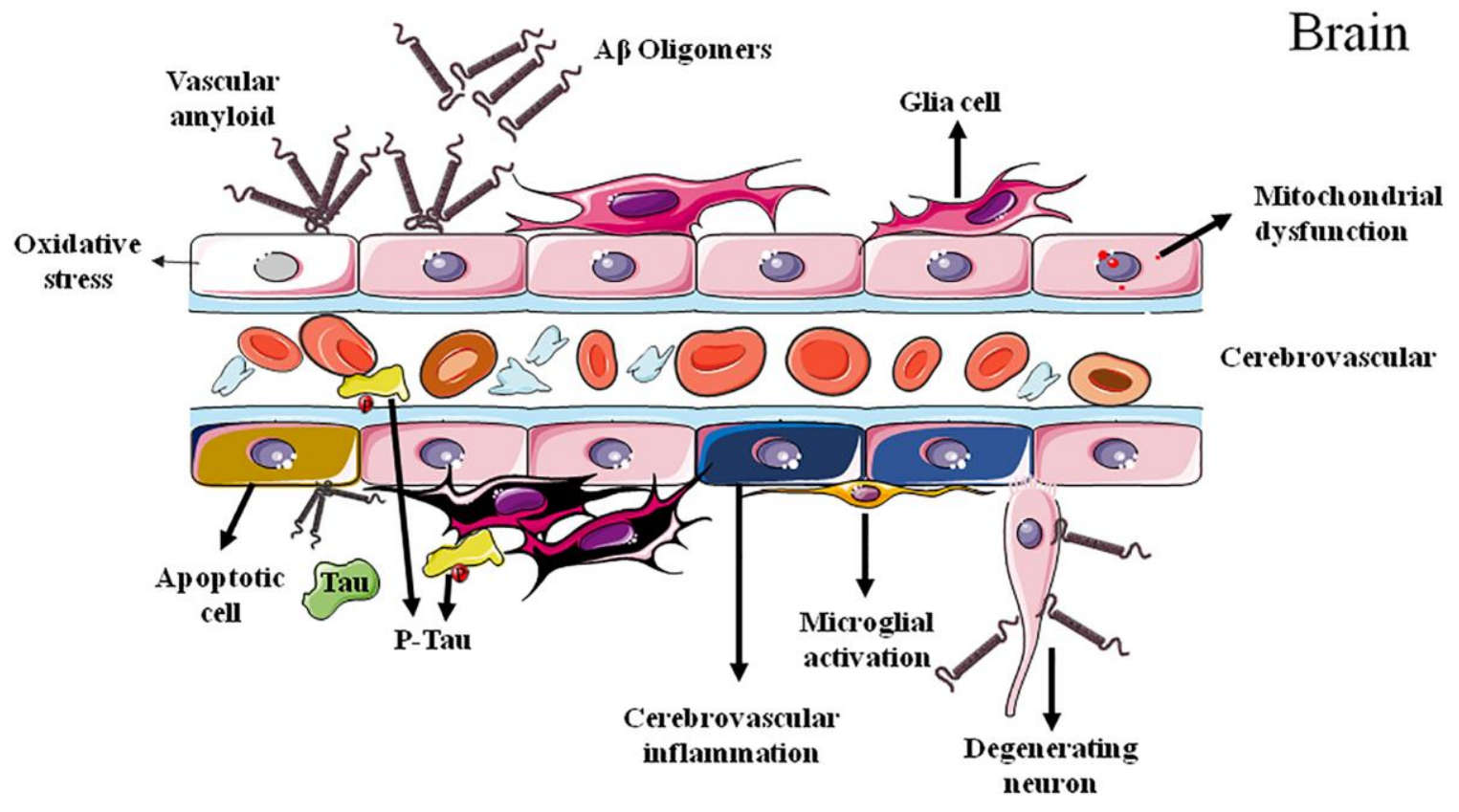

Figure 1. Cerebrovascular dysfunctions in Alzheimer's disease. 
parahippocampal gyrus [14]. Moreover, in APP/PS1 and 5xFAD mouse models of $\mathrm{AD}$, decreased $\mathrm{CBF}$ in cortical capillaries and impaired learning/memory ability was observed, which can be immediately ameliorated by the administration of antibodies against the neutrophil marker Ly6G [15]. The association between $\mathrm{CBF}$ alterations and $\mathrm{AD}$ pathologies can be observed in older adults without dementia. Nondemented individuals bearing high $\mathrm{A} \beta$ deposition in the brain showed declined $\mathrm{CBF}$ in right anterior to middle cingulate, right supramarginal gyrus, left thalamus, and midbrain bilaterally, as well as increase CBF in left medial and inferior frontal gyri, right precuneus, left inferior parietal lobule, and left postcentral gyrus, in the years preceding the neuroimaging acquisition [16]. Patients with amnestic MCI also showed a decreased cerebral perfusion [17] and this declined CBF in specific brain regions can be used as marker for identifying those MCI patients with high risk of rapidly progressing to AD in up to 3 years [17-21].

\section{Abnormal blood-brain barrier integrity in AD}

Clinical and experimental studies have revealed disruptions of $\mathrm{BBB}$ integrity in $\mathrm{AD}[22,23]$. Much more interestingly, brain capillary damage and $\mathrm{BBB}$ breakdown in the hippocampus of individuals with early cognitive dysfunction were irrespective of the alterations of $A \beta$ and/or tau pathologies, suggesting the promising potential as early biomarker for AD [24]. Additionally, pericytes maintain $\mathrm{BBB}$ integrity and clear $A \beta$ from the brain, and their degeneration leads to BBB breakdown and accelerates the onset and progression of $A \beta$ and tau pathology in mouse models of $\mathrm{AD}[25,26]$. Moreover, tissue from $\mathrm{AD}$ brains exhibited BBB leakiness and altered blood vessels morphologies, accompanied with amplified microglia reactivity and inflammation [27].

\section{Abnormal cerebrovascular reactivity in AD}

Recent evidence suggests a close relationship between cerebrovascular function and AD. Cerebral hemodynamic alterations and decreased vascular density were found in the brain of APP/PS1 transgenic AD model mice [28]. Consistently, Hong et al. also found that, compare to wild-type control mice, APP/PS1 transgenic $\mathrm{AD}$ mice showed an increased cerebrovascular reactivity to ATP, which can be ameliorated by exercise training through $\mathrm{P} 2 \mathrm{Y} 2$ receptor-mediated eNOS signaling and reducing ER stress [29]. Interestingly, the reactivity of large arteries was not affected in $\mathrm{AD}$ mice. Moreover, circulating $\mathrm{A} \beta$ might be responsible for the impaired peripheral vasculature repair mechanisms. These results were consistent with the Kelle et al. study, in which APP/PS1 transgenic mice showed a significant reduction of hepatic vessel number [12]. All these findings may suggest that vascular dysfunction in $\mathrm{AD}$ is a systemic alteration, both central and peripheral. Assessment of peripheral vasculature or vascular function may therefore provide additional tools for early diagnosis and management of AD.

\section{Cerebrovascular abnormalities as early sign of AD}

Microvascular ultrastructural changes in brain of APP/PS1 AD model mice have been reported to precede cognitive impairment [12]. Despite those preclinical experimental findings in $\mathrm{AD}$ animal models, clinical studies of patients with $\mathrm{AD}$ also revealed early cerebrovascular dysfunctions prior to significant $\mathrm{AD}$ symptoms [30-33]. Moreover, brain capillary damage and BBB breakdown in the hippocampus of individuals with early cognitive dysfunction were irrespective of the alterations of $A \beta$ and/or tau pathologies [24]. One recent cross-sectional study also provided Class II evidence that cerebrovascular reactivity in patients with cognitive impairment can predict cognitive performance independently of $\mathrm{AD}$ pathologic biomarkers [6], suggesting cerebrovascular abnormalities could be an early sign for $\mathrm{AD}$.

Furthermore, during the very early stage of AD, PS1 mutation has been found to induce a decrease in cerebral perfusion in the hippocampal-amygdaloid complex and in the anterior and posterior cingulated cortex [34]. Similarly, individuals carrying high AD-risky apolipoprotein E\&4 (ApoE- $\varepsilon 4)$ allele showed a BBB breakdown and decreased CBF over time in the frontal, parietal and temporal cortices, preceding the occurrence of cognitive decline $[35,36]$. These alterations were also independent of $A \beta$ or tau pathology [36]. Therefore, $\mathrm{CBF}$ reductions in specific brain regions may be proposed as the early biomarker of the development and progression of $\mathrm{AD}[32,33]$. Much more interestingly, the higher basal level of soluble platelet-derived growth factor receptor $\beta$ (PDGFR $\beta$ ), one reliable BBB pericyte injury biomarker in the cerebrospinal fluid (CSF), may predict future cognitive impairment in APOE4 carriers but not in those non-carriers. These findings suggested that the abnormal structure or function of BBB contributes to APOE4-associated cognitive decline independent of $\mathrm{AD}$ pathology and might be a therapeutic target in AD patients carrying APOE4 [36].

\section{Interplays between AD pathologies and cerebro- vascular alterations}

As mentioned above, cerebrovascular abnormalities accompany and even precede the classical $\mathrm{A} \beta$ and tau hallmarks of $\mathrm{AD}$, suggesting potential pathological interactions between cerebrovascular alterations and $\mathrm{AD}$ 
pathologies. In fact, polygenic risk scores for AD have been reported to be associated with various vascular events, including lobar cerebral microbleeds, white matter lesion load, and coronary artery calcification, suggesting vascular pathologies as an important target for future $\mathrm{AD}$ mechanistic research [37].

\section{A $\beta$-mediated vascular endothelial damage, blood- flow decline and vasoactivity}

The A $\beta$ precursor protein (APP) expression can be detected in vascular endothelium of both central and peripheral blood vessels. Expression and activity of the key enzymes responsible for both non-amyloidogenic and amyloidogenic processing of APP have also been detected in endothelial cells [38]. Intriguingly, expression of APP751 and APP770 isoforms is higher in endothelial cells of cerebral blood vessels than in those of peripheral arteries [39], predicting a more serious pathophysiological reactivity of cerebrovascular to $A \beta$.

$\mathrm{CBF}$ reduction has been recognized as an early sign of $\mathrm{AD}$ onset. Nortley et al. found that $\mathrm{A} \beta$ induced brain capillaries constriction at pericyte locations in biopsied human tissue of demented patients, via overproduction of reactive oxygen species (ROS) and subsequently the release of endothelin-1. Consistently, similar capillary constriction has also been observed in App ${ }^{\text {NL-G-F }}$ knockin mouse model of $\mathrm{AD}[40]$. Therefore, the A $\beta$-induced cerebral capillaries constriction may contribute to the energy lack and neurodegeneration in $\mathrm{AD}$, and the inhibition of the capillary constriction caused by $\mathrm{A} \beta$ could potentially reduce pathological consequences of $\mathrm{A} \beta$ [40]. Further experimental evidence has specifically supported the deleterious impacts of $A \beta$ on cerebrovascular function [41-43] (Table 1). For example, short-term incubation of arteries with $A \beta$ increases the vasoconstrictions to phenylephrine, serotonin, and endothelin-1 [44-47]. A $\beta$ accumulation, due to either elevated production or declined clearance, can induce arterial vasoconstriction, reduce $\mathrm{CBF}$ and lead to impairment of functional hyperemia [48-51]. It is worth noting that neurotoxic $A \beta_{42}$ oligomer can also dosedependently induced vessel disruption and reduced angiogenesis, which can be prevented by epidermal growth factor, suggesting angiogenic pathway as potential target for $\mathrm{AD}$ therapy [52].

Several possible molecular mechanisms have been identified to be responsible for $\mathrm{A} \beta$-induced $\mathrm{CBF}$ reduction and cerebrovascular constriction, including the increased production of prostaglandins and ROS. Furthermore, incubation of cerebral arteries with $A \beta$ impairs endothelium-dependent relaxations which can be reversed by free radical scavenger superoxide dismutase, supporting the involvement of increased
ROS production and decreased eNOS activity in endothelial dysfunction $[42,44,50,53]$. This vasoconstriction activity of $A \beta$ might be also mediated by the altered function of the neurovascular unit (NVU) $[54,55]$ or $\alpha 1$ adrenergic receptor [47].

Despite the vascular tone, platelet aggregation also impacts the blood perfusion in brain. Platelets can attach to vascular amyloid depositions and thereafter initiate platelet activation, which induces hemostatic plug and vascular occlusion in the brain and leads to insufficient $\mathrm{CBF}$. On the other hand, $\mathrm{A} \beta$ can bind to the integrin $\alpha \operatorname{IIb} \beta 3$ on platelets and stimulate the secretion of clusterin, which in turn promoted $A \beta$ aggregation [56].

\section{Tau induces blood vessel abnormalities and cerebral blood flow changes}

Despite $A \beta$, the pathological alterations of tau have also been reported to contribute to the cerebrovascular abnormalities in $\mathrm{AD}$. Bennett et al. reported abnormal vascular morphologies, decreased vessel diameters and increased vessel densities in cortex in $\mathrm{Tg} 4510$ mice overexpressing P301L tau [57], which were concurrently accompanied by cortical atrophy and increased angiogenesis-related genes expression. Interestingly, all these cortical atrophy or blood vessel changes were not observed in $\mathrm{Tg} 21221$ mice overexpressing wild-type tau. Worth noting, $A \beta$ accumulation in aged APP/PS1 mouse model of AD failed to induce plasminogen activation inhibitor 1 expression or similar blood vessel changes [58].

In addition, PS19 mice expressing mutant P301S tau and Tg4510 mice expressing P301L tau exhibit reduced vasodilatation of intracerebral arterioles and a suppressed CBF induction by neural activity, which precedes tau pathology and cognitive decline and can be reversed by reducing tau production [58]. All these vascular dysfunctions might be due to a tau-induced dissociation of neuronal nitric oxide synthase (nNOS) and reduction of nitric oxide (NO) during glutamatergic synaptic activity, indicating the glutamatergic signaling dysfunction and NO deficiency as early signs of tau pathology and providing a possible mechanism for the neurovascular alterations in the prodromal phase of $\mathrm{AD}$ [58].

\section{Cerebrovascular alterations induce and promote amyloidopathy in AD}

The potential impacts of cerebrovascular abnormalities on amyloidopathy have been extensively investigated by detecting the susceptibility of developing $\mathrm{AD}$ pathologies under the reduced cerebral perfusion conditions in various animal models $[59,60]$. Cerebral 
Table 1. Effects of $A \beta$ on isolated cerebral blood vessels [52].

\begin{tabular}{|c|c|c|c|c|}
\hline Vessel types & A $\beta$ types & Concentration range & Cellular and/or molecular mechanisms of $A \beta$ & References \\
\hline \multirow[t]{2}{*}{ Rat cerebral artery } & $\mathrm{A} \beta 1-40$ & $0.0001-1 \mu \mathrm{M}$ & Impaired endothelium-dependent relaxation to ACh & {$[56]$} \\
\hline & $A \beta 25-35$ & $0.0001-1 \mu \mathrm{M}$ & & \\
\hline \multirow[t]{2}{*}{ Mouse cerebral artery } & $\mathrm{A} \beta 1-40$ & $0.01-10 \mu \mathrm{M}$ & Decreased cerebral blood flow to ACh & {$[58,68]$} \\
\hline & $\mathrm{A} \beta 1-42$ & $0.01-10 \mu \mathrm{M}$ & No change observed & \\
\hline Rat penetrating cerebral arterioles & $\begin{array}{l}\mathrm{A} \beta 1-40 \\
\mathrm{~A} \beta 1-42\end{array}$ & $0.001-1 \mu \mathrm{M}$ & $\begin{array}{l}\text { Reduction of tone diameter by increased contraction; } \\
\text { decreased endothelium-dependent relaxation to ATP }\end{array}$ & {$[65]$} \\
\hline Human middle cerebral artery & $\mathrm{A} \beta 1-40$ & $1 \mu \mathrm{M}$ & $\begin{array}{l}\text { Increased contractions to endothelin- } 1 \text { via } \mathrm{COX}-2 \text { and } \\
\text { p38 mitogen-activated protein kinase activation }\end{array}$ & {$[61]$} \\
\hline Human middle cerebral artery & $\mathrm{A} \beta 1-40$ & $2 \mu \mathrm{M}$ & Increased production of PGF2 $\alpha$ and PGE2 & {$[61]$} \\
\hline Bovine middle cerebral artery & $\mathrm{A} \beta 1-40$ & $1 \mu \mathrm{M}$ & $\begin{array}{c}\text { Impaired endothelium-dependent relaxation to } \\
\text { bradykinin }\end{array}$ & {$[57]$} \\
\hline
\end{tabular}

circulatory disturbance via the alterations of cerebrovascular structure or function may induce or exacerbate progressive neuronal loss in $\mathrm{AD}$ brain. Indeed, while intensive studies have focused on $A \beta$ - and tau-related neuronal damages, increasing lines of evidence suggests the pivotal roles of vascular alterations in the pathogenesis and progression of $\mathrm{AD}$ [61]. According to the "Two-hit vascular hypothesis of $A D$ ", the cerebrovascular damage preceding $\mathrm{A} \beta$ pathology is the initial insult of AD process. Reduced blood flow, BBB breakdown and altered vascular reactivity are self-sufficient to initiate neuronal injury and cognitive impairment (hit 1 ), and also subsequently alter $A \beta$ production $[60,62,63]$ and $A \beta$ clearance [64] (hit 2). Faulty $A \beta$ clearance itself may be the pathological consequence of arterial stiffness, which reduces the exchange of $A \beta$ between interstitial fluid and CSF and leads to abnormal $A \beta$ accumulation in brain [65]. ADAMTS13 deficiency led to an early and progressive damage of $\mathrm{BBB}$ together with reduced vessel density and decreased CBF in APP/PS1 model mice of $\mathrm{AD}$. These cerebrovascular abnormalities induced by deficiency of ADAMTS 13 also impeded A $\beta$ clearance and consequently increased $A \beta$ levels to exacerbate brain plaque load and cerebral amyloid angiopathy (CAA), resulting in worse cognitive decline in APP/PS1 mice. Interestingly, restoration of ADAMTS13 expression can attenuate BBB disruption, increase capillary perfusion, and ameliorate the CBF reduction in APP/PS1 mice. All these results confirmed the contribution of cerebrovascular alterations to $A \beta$ pathology and further suggested ADAMTS13 as a novel target for AD therapy [66].

\section{Cerebrovascular alterations induce and promote tauopathy in AD}

Despite A $\beta$ pathology, the associations between vascular and tau and their effects on cognition have also been confirmed by voxelwise comparisons between $\mathrm{CBF}$ and tau PET images in independent discovery and replication cohorts. In participants with higher amyloid burden in brain and lower scores of Montreal cognitive assessment, strong correlation between soluble plateletderived growth factor $\beta$ and tau and correlation between CBF and tau were observed [67]. Laing et al. found that in $\mathrm{AD}$ patients, the volume of white matter of hyperintensity was positively correlated with plasma tau. Brain amyloid burden and the interaction between plasma tau and white matter of hyperintensity could distinguish $\mathrm{AD}$ and MCI patients from controls, with accuracies as $77.6 \%$ and $63.3 \%$, respectively. Moreover, increased tau levels in plasma and CSF and hyperphosphorylated tau level in the ipsilateral hippocampus and cerebral hemisphere were observed in aged mice subjected to transient focal cerebral ischemia [68]. All these findings suggested cerebrovascular dysfunctions could induce and promote tau pathology in $\mathrm{AD}$. Combination treatments targeting cerebrovascular, $\mathrm{A} \beta$, and tau may be more effective to prevent or delay the pathogenesis or progression of $\mathrm{AD}$ than singletarget therapies.

The chronic reduction of blood flow and thereafter impaired cerebral metabolism may deteriorate $A \beta$ and tau pathologies through various molecular mechanisms. The $A \beta /$ tau-neurovascular interactions are likely to fuel one another in deleterious vicious circles. Recently, Zhang et al. found that $A \beta$ oligomers could be associated with $\alpha 2 \mathrm{~A}$ adrenergic receptor to induce glycogen synthase kinase $3 \beta$ (GSK3 $\beta$ ) activation and thereafter tau hyperphosphorylation [69], suggesting the possible involvement of adrenergic mechanism in cerebrovascular dysfunction and AD pathology.

\section{Adrenergic mechanisms underlying $A \beta /$ tau- cerebrovascular interactions}

The adrenergic signaling, as one of the major modulators of cerebrovascular reactivity and $\mathrm{CBF}$, mediates its effects in blood vessels through various adrenergic receptors (also called adrenoceptors, ARs). 
ARs are a part of membrane-bound G-protein-coupled receptors (GPCRs) that mediate the peripheral and central actions of norepinephrine and epinephrine. Due to their distributions, either presynaptically or postsynaptically on neurons or effector organs such as the heart, vasculature, and adipose tissue, ARs mediate a broad range of important physiological homeostatic responses. ARs are classified into two main categories, $\alpha$ and $\beta$. The $\alpha$ type is further divided into $\alpha 1$ and $\alpha 2$ which are subdivided into $\alpha 1 \mathrm{~A}, \alpha 1 \mathrm{~B}, \alpha 1 \mathrm{D}$ and $\alpha 2 \mathrm{~A}$, $\alpha 2 \mathrm{~B}$ and $\alpha 2 \mathrm{C}$, respectively. $\beta$-ARs are classified into $\beta 1$, $\beta 2$ and $\beta 3$ subgroups. Increasing evidence may predict the important roles of ARs and related signaling in the pathogenesis and progression of $\mathrm{AD}$.

\section{a1-adrenoceptor}

The $\alpha 1-\mathrm{AR}$ is one of the ARs that play important roles in the regulation of vessel musculature. As a GPCR, the activated $\alpha 1-\mathrm{AR}$ couples with the $\mathrm{Gq}$ protein to activate phospholipase $\mathrm{C}$, which cleaves phosphatidylinositol4,5-bisphosphate into diacylglycerol and inositol trisphosphate, two second messenger molecules influencing cellular calcium homeostasis and activating PKC/ERK pathway to induce vasocontraction and cell proliferation (as summarized in Figure 2).

Increasing lines of evidence have been provided to support the deleterious roles of $A \beta$ on cerebrovascular function [44]. Much more specifically, Haase et al. further found that $A \beta 25-35$, the toxic fragment of $A \beta$, induced vasoconstriction of mouse aortic rings and coronary arteries in Langendoff-perfused rat hearts, which could be reversed by $\alpha 1-\mathrm{AR}$ blockage [47]. Consistently, agonistic autoantibodies (agAAB) for $\alpha 1$-AR have been found to exert similar impacts as $A \beta$ did. $\alpha 1$-AR-agAABs were detected in about $50 \%$ of AD patients. These agAABs showed similar bioactivity as natural agonists do, such as $\mathrm{A} \beta$, and bind to $\alpha 1$-AR to induce significant elevation of intracellular calcium. Moreover, these agAABs could cause vascular impairment in the brain of animal model, as shown by the significant $\mathrm{CBF}$ reductions and vessels damage. Interestingly, a subsequent 12-18 months follow-up observations found a stabilized cognitive performance while agAABs were removed by immunoadsorption in $\mathrm{AD}$ patients [70, 71]. All these data may predict the important roles of $\alpha 1$-AR-related vascular-pathologies in $\mathrm{AD}$ pathogenesis and progression.

\section{a2-adrenoceptor}

Adrenaline or noradrenaline induce vasoconstriction through both $\alpha 1$ - and $\alpha 2$-AR [72]. The $\alpha 2$-AR expresses in both endothelial cells and smooth muscle cells of vascular [73]. Interestingly, while the endothelial $\alpha 2-\mathrm{AR}$ induces vasorelaxation, the activation of $\alpha 2-\mathrm{AR}$ in vascular smooth muscle cells leads to vasoconstriction [74]. Although the signal transduction pathways behind a1-AR-mediated vasoconstriction have been well established, the exact mechanisms underlying $\alpha 2$-ARmediated vasoconstriction are still largely unknown.

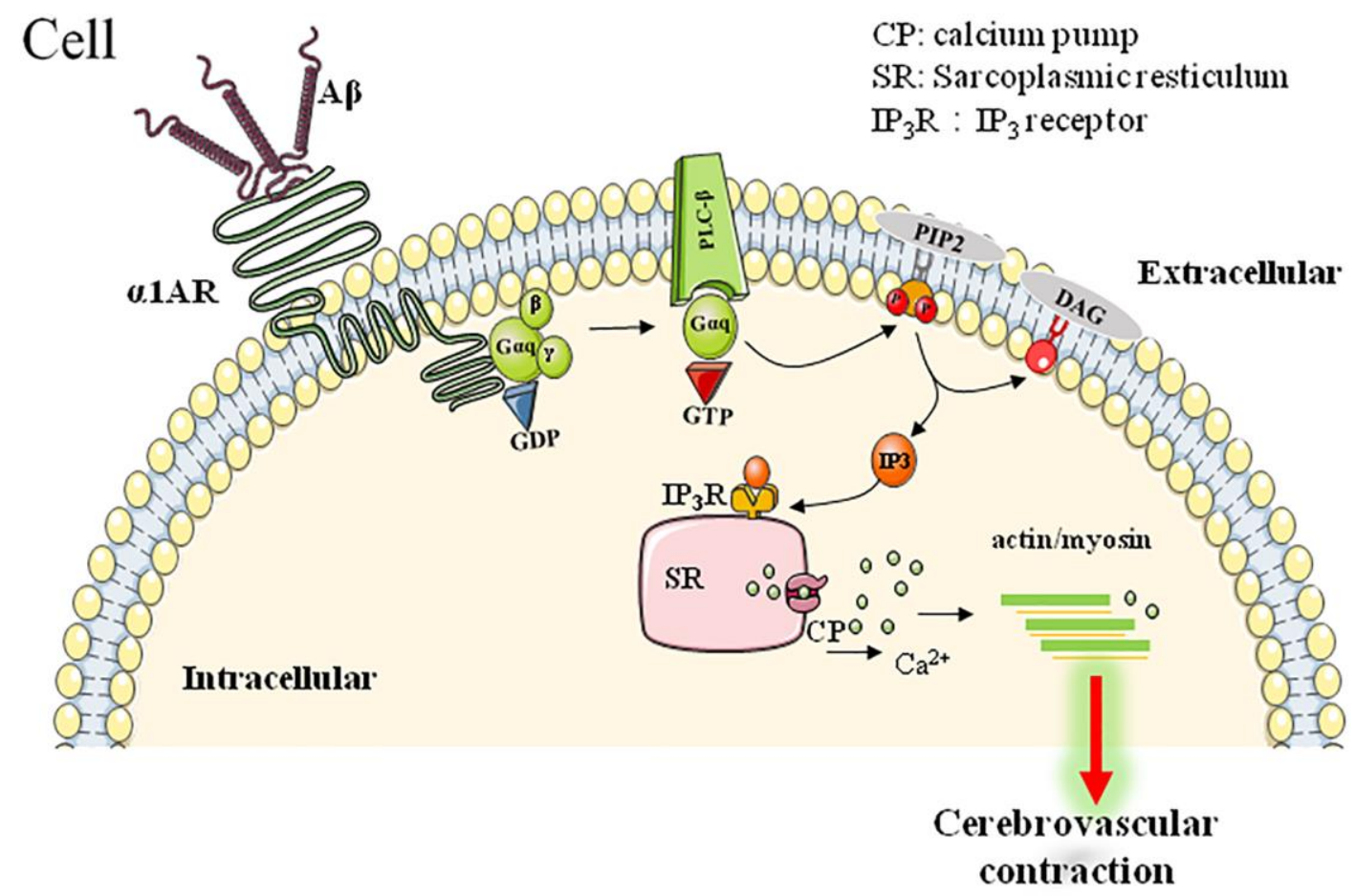

Figure 2. $\alpha 1 A R$-mediated downstream signaling pathway involved in A $\beta$-induced cerebrovascular abnormalities. 
$\alpha 2-\mathrm{AR}$ is coupled to Gi-protein and activation of $\alpha 2-\mathrm{AR}$ leads to a decreased intracellular cAMP level, which in turn results in constriction of vascular smooth muscle and an increased blood vessel tone. Moreover, cAMP/AC independent mechanisms have also been found to be involved in the $\alpha 2$-AR-mediated vasoconstriction. For example, $\alpha 2-\mathrm{AR}$ can induce the vasoconstriction in the porcine palmar lateral vein via the activation of ERKdependent signaling pathway and Src tyrosine kinases [75]. Interestingly, compared to nondemented, low pathology control subjects, AD patients showed a significant increase of $\alpha 2 \mathrm{~A}-\mathrm{AR}$ activity. Moreover, administration of $\alpha 2 \mathrm{~A}-\mathrm{AR}$ activator clonidine resulted in worsened cognitive function in demented patients but not in non-demented normal subjects [69]. Although up to date no experimental evidence have revealed the direct binding of $\mathrm{A} \beta$ with vascular $\alpha 2 \mathrm{~A}-\mathrm{AR}$ to modulate vascular function, $A \beta$ oligomers but not monomer has been reported to interact with $\alpha 2 \mathrm{~A}-\mathrm{AR}$ in $\alpha 2 \mathrm{~A}-\mathrm{AR}$ overexpressed HEK293 cells. Moreover, A $\beta$ oligomers can bind to allosteric site on $\alpha 2 \mathrm{~A}-\mathrm{AR}$ to redirect norepinephrine-elicited signaling to GSK3 $\beta$ activation and so as to induce tau hyperphosphorylation [69]. Moreover, dexmedetomidine, an $\alpha 2$-AR selective agonist, induced a persistent hyperphosphorylation of tau in mouse hippocampus, which can be blocked by $\alpha 2-\mathrm{AR}$ specific antagonist atipamezole [76].

\section{B2-adrenoceptor}

Despite $\alpha$-AR, $\beta$-AR, especially $\beta 2-\mathrm{AR}$, is also an important target for modulating vascular tone. In general, acute $\beta$-AR activation induces vasodilation. However, chronic stimulation of $\beta$-AR led to an altered vascular responsibility to contractive insults. Chronic exposure of isoproterenol, a synthetic $\beta$ adrenergic agonist, induced endothelial dysfunction and consequently an increased vasoconstrictive responsibility to phenylephrine [77]. The enhanced vasoconstrictor response and oxidative stress level induced by isoproterenol treatment might be due to the endothelial nitric oxide synthase (eNOS) uncoupling, through the downstream signaling pathway of $\beta 2-A R$ [78]. Previous studies have indicated that the stressinduced overproduction of catecholamines produce coronary spasms or arrhythmias via abnormal calcium signaling and impaired mitochondrial function. Notably, increased $\beta 2$-AR expression level has been found in the brains of $\mathrm{AD}$ patients and $\beta$-blockers decrease the incidence of $\mathrm{AD}$. In fact, several lines of evidence have supported the binding of $A \beta$ with $\beta$-AR. Wang et al. revealed that $A \beta$ has a binding capacity to $\beta 2-A R$ and induces PKA-dependent hyperactivity in AMPA receptors [79]. A $\beta$ has been reported to induce tau phosphorylation at Ser-214, Ser-262 and Thr-181 through activating $\beta 2$-AR-PKA-JNK signaling pathway in primary PFC neurons. Moreover, $A \beta$ can also activate
arrestin-ERK1/2 pathway in a $\beta 2$-AR-dependent manner. In contrast, the $A \beta$-induced tau phosphorylation at Thr181 can be partially reversed by inhibition of MEK, an upstream molecule of ERK1/2 [80]. All these findings indicated that $\mathrm{A} \beta$ could induce cerebral vascular dysfunction at least partially through $\beta 2-\mathrm{AR}$ and its downstream signaling pathways. Much more importantly, activation of $\beta 2-\mathrm{AR}$ could stimulate $\gamma$ secretase to promote the formation of amyloid plaque, which may predict a feed-back loop and vicious cycle to promote the progression of $\mathrm{AD}$.

As for the correlation between $\beta 2-\mathrm{AR}$ and tau pathology of $\mathrm{AD}$, deletion of the $\beta 2-\mathrm{AR}$ showed a reduced mortality and significantly improved motor deficits in tau transgenic mice. The improved lifespan and motor function was associated with a reduction in brain tau immunoreactivity and phosphorylation. The $\beta 2$-ARmediated changes in tau might be due to the reduced activity of GSK3 $\beta$ and cyclin-dependent kinase 5, two kinases responsible for tau phosphorylation [81].

\section{$\beta 1-$ and $\beta 3$-adrenoceptors}

Based on early pharmacological studies, the $\beta 2$-AR was thought to be the major vascular responsive $\beta$-AR subtype, whereas $\beta 1$ and $\beta 3$ are primarily distributed in cardiomyocytes and adipocytes, respectively. However, experimental findings also reported that $\beta 1$ and $\beta 3$ ARs also play potential roles in the cerebrovasculature [82]. Previous studies found that chronic administration of CL316243, a specific $\beta 3$ AR agonist, reversed the cognitive impairment and the elevated insoluble $\mathrm{A} \beta 42 / \mathrm{A} \beta 40$ ratio in 16-month-old 3xTg-AD mice [83]. of CL316243 administration also specifically stimulated astrocytic but not neuronal glucose uptake and rescue the impaired cognitive function induced by $\mathrm{A} \beta$ [84]. As for $\beta 1-\mathrm{AR}$, chronic treatment with xamoterol, a selective, functionally biased, partial agonist of $\beta 1-\mathrm{AR}$, was effective to ameliorate cognitive deficits and reduce neuroinflammation and $A \beta /$ tau pathologies in transgenic mouse models of AD [85, 86]. Furthermore, consistent with these findings, in APP transgenic mouse model of $\mathrm{AD}$, chronic $\beta$-blockers administration potentiated CNS inflammation, whereas the $\beta$-blocker, metoprolol, induced phagocytosis and impaired cognitive behavior in both wild-type and APP transgenic mouse [87]. However, to date no direct evidence has implicated the involvement of $\beta 1-$ or $\beta 3-\mathrm{AR}$ in the interactions of abnormal cerebrovascularure and $A \beta /$ tau pathologies of $A D$.

\section{Clinical implications of cerebrovascular abnormality on AD early diagnosis and therapy}

To-date, no clinically relevant therapies have been achieved addressing abnormal neurovascular functions 
of $\mathrm{AD}$, aside from the reduced risk associated with diabetes and atherosclerosis. However, several clinical trials evaluated the therapeutic potential of adrenergicagents against $\mathrm{AD}$, including $\alpha 2 \mathrm{C} \mathrm{AR}$ antagonist ORM12741 (https://clinicaltrials.gov/ct2/show/NCT01324518) and $\beta 2$ AR agonist formoterol (https://clinicaltrials.gov/ ct2/show/NCT02500784).

Several clinical trials have confirmed the benefits of $\alpha 1$ antagonist prazosin on AD. Several clinical trials have assessed the effectiveness of prazosin, one $\alpha 1$ AR antagonist, in $\mathrm{AD}$. For examples, one randomized, placebo-controlled study in 24 patients suggested that prazosin significantly psychiatric symptoms of $\mathrm{AD}$ including agitation and aggression in $\mathrm{AD}$ patients, compared with the placebo-treated group. Another clinical trial found an improved behavior of AD patients after a 12-week period prazosin treatment compared with placebo control subjects. Moreover, another one synthetic $\alpha$-AR blocker nicergoline also showed therapeutic potential against AD. Nicergoline has been found to enhance the cholinergic and catecholaminergic neurotransmission, improve the age-related cognitive deficits, and modulate protein kinase $\mathrm{C}$ (PKC)-mediated $\alpha$-secretase processing of APP. Nicergoline has also been found to be neuroprotective and involved in the endogenous nerve growth factor-mediated processes. Nicergoline has been clinically used as therapeutics of cerebral metabolic-vascular disorders, vascular migraines, and dementia. In a European multicenter double-blind and placebo-controlled trial, nicergoline exerted a positive effect on the cognitive symptoms of mild-to-moderate $\mathrm{AD}$ [88].

\section{Retinal vascular changes as biomarker of AD}

$\mathrm{AD}$ is pathologically characterized by progressive accumulation of $A \beta$, tau hyperphosphorylation, and progressive neurodegeneration. Pathological senile plaques and neurofibrillary tangles in brain have been accepted as hallmarks of AD. In addition, vascular changes occur at early stage of $\mathrm{AD}$ and are also involved in $\mathrm{AD}$ pathophysiology. Vascular changes may exacerbate $\mathrm{A} \beta$ pathology of $\mathrm{AD}$ through inhibiting $A \beta$ clearance from the brain $[89,90]$, promoting influx of peripheral $A \beta$ through the BBB [91], increasing APP expression [92, 93], which contribute to $A \beta$ accumulation both in the parenchyma and blood vessels [94]. Consistently, altered BBB permeability and function precedes $A \beta$ pathology and cognitive impairment of AD [95]. Therefore, assessment of vascular microstructure or function may provide valuable biomarker for early diagnosis of AD. Vascular signs may serve as novel biomarkers to provide pathophysiological insight for early diagnosis of $\mathrm{AD}$. Although the currently used biomarkers for vascular changes are limited to MRI [96], recent research reports have indicated the possibility of using retinal capillary imaging as potential technique for $\mathrm{AD}$ diagnosis. For example, compare to wild-type mice, a significant retinal capillary degeneration in APP/PS1 mice was found as early as 8-month of age and was significantly worse during $\mathrm{AD}$ progression. This capillaries degeneration was correlated with substantial vascular PDGFR $\beta$ deficiency and prominent vascular $A \beta$ deposition. Moreover, tightjunction alterations such as downregulated claudin-1 expression and increased permeability of brain-retinabarrier (BRB) were also found in APP/PS1 mice [97]. This retinal capillary degeneration and compromised $\mathrm{BRB}$ integrity at early stages in $\mathrm{AD}$ mouse may provide a new strategy for development of novel targets for $\mathrm{AD}$ diagnosis. Consistently, maximal venous and arterial reactions to monochromatic flicker stimulation were increased in AD patients as compared to healthy control and to subjects with MCI. Moreover, the arterial flicker response curve differed in MCI as compared to healthy control, as evidenced by significantly higher reactive magnitude and the more emphasized constriction in MCI [98]. These findings suggest that retinal structure or function is damaged during the early stage of $\mathrm{AD}$. The retinal vessel reaction to flicker stimulation could be considered as a promising non-invasive and easy-to-administer biomarker for the diagnosis and monitoring of $\mathrm{AD}$ [98]. Similarly, Golzan et al. found that the amplitude of retinal venous pulsations was negatively correlated with the neocortical A $\beta$ load, whereas the amplitude of retinal arterial pulsations was positively correlated with neocortical $A \beta$ load. Retinal ganglion cell layer thickness was significantly decreased in AD patients. The correlation between retinal vascular alterations and $\mathrm{A} \beta$ load predicts a vascular component to $\mathrm{AD}$ pathogenesis and progression. Dynamic monitor of retinal vascular may provide reliable marker to aid in the assessment of $\mathrm{AD}$ during preclinical phase without significant cognitive manifestations [99]. Worth noting, one study in 2019, found that retinal vasculature did not discriminate $\mathrm{AD}$ patients from healthy controls [100]. However, much more recent experimental data were reported to support the utility of retinal vascular changes as potential marker of $\mathrm{AD}$ [75, 101-104].

\section{Cerebrovascular-targeting therapy against AD}

While the current therapeutic strategies based on ATN theories yield very limited benefits against $\mathrm{AD}$, recent studies have indicated that vascular lesions of dysfunction are involved in the pathogenesis and progression of AD. Various vascular events have been found to precede the 
pathological changes and clinical symptoms of $\mathrm{AD}$, and vascular lesions share many common risk factors with AD. Vascular-recovering or remodeling may provide novel strategies to prevent the pathogenesis or delay progress of AD.

Microangiopathies have been found in APP/PS1 mice at 9 months of age, which can be ameliorated by administration of Liraglutide [105]. Consistently, implantation of mesenchymal stem cell-derived pericytes, the well-accepted modulator of cerebral vascular function, increased the brain microcirculation in APP/PS1 mice at the age of 18 to 20 months. Importantly, the levels of insoluble $A \beta 40$ and $A \beta 42$ together with the $A \beta$ deposition were significantly reduced in hippocampus of the pericyte-injected hemisphere of APP/PS1 mice than that of the contralateral side. These findings indicated that the remodeling cerebral vascular via cell-based therapy can reduce brain $A \beta$-related pathologies, and could serve as a promising strategy for $\mathrm{AD}$ prevention and therapy [106].

Much more specifically, treatment of nicergoline, a selective $\alpha 1 \mathrm{~A}-\mathrm{AR}$ blocker, may be beneficial to the severity of cognitive impairment, of daily living activities decline, and psychiatric symptoms in early $\mathrm{AD}$ patients. The follow-up study further revealed significant increases of relative regional $\mathrm{CBF}$ in $\mathrm{AD}$ patients. The increased perfusion in the superior frontal gyrus may be related to the delay or prevention of progressive cognitive deterioration in AD [107].

\section{CONCLUSIONS}

$\mathrm{AD}$ is the most common cause of dementia, accounting for about $60 \%$ to $80 \%$ of cases. The pathological hallmarks including $A \beta$ (plaques) and twisted strands of tau protein (tangles) are accompanied by progressive neurodegeneration and brain tissue damage. Unfortunately, so far, no therapeutic candidate, which inhibits $A \beta$ aggregation or tau phosphorylation, has been approved to treat $\mathrm{AD}$, and no satisfied early diagnostic scheme has been established for AD. The changes in CBF may impair cognition via promoting $A \beta$ and tau pathologies or directly inducing neurodegeneration. Abnormal adrenergic activities such as ARsignaling may be involved in this process. Increasing lines of evidence from either preclinical or clinical studies have revealed that the cerebral vascular alterations during early stages of $\mathrm{AD}$ may contribute to the pathogenesis and progression of the disease. Cerebral vascular assessment may provide promising tools for $\mathrm{AD}$ early diagnosis and cerebral vascular remodeling may yield benefits to AD therapy.

\section{AUTHOR CONTRIBUTIONS}

Song $\mathrm{Li}$ and Che Wang performed database search. Song Li, Che Wang, Zhen Wang and Jun Tan engaged in fruitful discussions about the content of manuscript. Song $\mathrm{Li}$ and Che Wang drafted, edited and finalized the manuscript. Zhen Wang edited the manuscript. Jun Tan contributes to the conception and design of manuscript. All the authors discussed the results and commented on the final version of the manuscript.

\section{ACKNOWLEDGMENTS}

The authors would thank Dr. Jiang Chen for his constructive comments during manuscript preparation and drawing the schematic diagrams.

\section{CONFLICTS OF INTEREST}

The authors declare no conflicts of interest related to this study.

\section{FUNDING}

This study was supported by the High-level Talent Foundation of Guizhou Medical University (YJ19017, HY2020, J.T.), National Natural Science Foundation of China (NSFC) (82060211, J.T.), the National Key Technologies R \& D Program of China during the 9th Five-Year Plan Period [4008 (2019), J.T.], and Zhejiang Provincial Natural Science foundation (LY19HH090013, ZW).

\section{REFERENCES}

1. 2021 Alzheimer's disease facts and figures. Alzheimers Dement. 2021; 17:327-406.

https://doi.org/10.1002/alz.12328

PMID:33756057

2. de la Torre JC. Alzheimer disease as a vascular disorder: nosological evidence. Stroke. 2002; 33:1152-62.

https://doi.org/10.1161/01.str.0000014421.15948.67 PMID:11935076

3. Royall DR. Alzheimer disease as a vascular disorder: nosological evidence. Stroke. 2002; 33:2147-48. https://doi.org/10.1161/01.str.0000028987.97497.22 PMID: 12215573

4. Sweeney MD, Montagne A, Sagare AP, Nation DA, Schneider LS, Chui HC, Harrington MG, Pa J, Law M, Wang DJJ, Jacobs RE, Doubal FN, Ramirez J, et al. 
Vascular dysfunction-The disregarded partner of Alzheimer's disease. Alzheimers Dement. 2019; 15:158-67.

https://doi.org/10.1016/j.jalz.2018.07.222 PMID: 30642436

5. Kisler K, Nelson AR, Montagne A, Zlokovic BV. Cerebral blood flow regulation and neurovascular dysfunction in Alzheimer disease. Nat Rev Neurosci. 2017; 18:419-34.

https://doi.org/10.1038/nrn.2017.48 PMID:28515434

6. Sur S, Lin Z, Li Y, Yasar S, Rosenberg P, Moghekar A, Hou X, Kalyani R, Hazel K, Pottanat G, Xu C, van Zijl P, Pillai J, et al. Association of cerebrovascular reactivity and Alzheimer pathologic markers with cognitive performance. Neurology. 2020; 95:e962-72. https://doi.org/10.1212/WNL.0000000000010133 PMID:32661101

7. Lao PJ, Gutierrez J, Keator D, Rizvi B, Banerjee A, Igwe KC, Laing KK, Sathishkumar M, Moni F, Andrews $H$, Krinsky-McHale S, Head E, Lee JH, et al. AlzheimerRelated Cerebrovascular Disease in Down Syndrome. Ann Neurol. 2020; 88:1165-77.

https://doi.org/10.1002/ana.25905

PMID:32944999

8. Slater C, Wang Q. Alzheimer's disease: An evolving understanding of noradrenergic involvement and the promising future of electroceutical therapies. Clin Transl Med. 2021; 11:e397.

https://doi.org/10.1002/ctm2.397

PMID:33931975

9. Jack CR Jr, Bennett DA, Blennow K, Carrillo MC, Dunn B, Haeberlein SB, Holtzman DM, Jagust W, Jessen F, Karlawish J, Liu E, Molinuevo JL, Montine T, et al, and Contributors. NIA-AA Research Framework: Toward a biological definition of Alzheimer's disease. Alzheimers Dement. 2018; 14:535-62.

https://doi.org/10.1016/j.jalz.2018.02.018 PMID:29653606

10. Ebenau JL, Timmers T, Wesselman LMP, Verberk IMW, Verfaillie SCJ, Slot RER, van Harten AC, Teunissen CE, Barkhof $F$, van den Bosch $K A$, van Leeuwenstijn $M$, Tomassen J, Braber AD, et al. ATN classification and clinical progression in subjective cognitive decline: The SCIENCe project. Neurology. 2020; 95:e46-58. https://doi.org/10.1212/WNL.0000000000009724 PMID: $\underline{32522798}$

11. Kimura T, Hashimura T, Miyakawa T. Observations of microvessels in the brain with Alzheimer's disease by the scanning electron microscopy. Jpn J Psychiatry Neurol. 1991; 45:671-76.

https://doi.org/10.1111/i.1440-1819.1991.tb01189.x PMID: 1800815
12. Kelly $P$, Denver $P$, Satchell SC, Ackermann $M$, Konerding MA, Mitchell CA. Microvascular ultrastructural changes precede cognitive impairment in the murine APPswe/PS1dE9 model of Alzheimer's disease. Angiogenesis. 2017; 20:567-80.

https://doi.org/10.1007/s10456-017-9568-3 PMID:28741167

13. Merkulova-Rainon $T$, Mantsounga CS, Broquères-You D, Pinto C, Vilar J, Cifuentes D, Bonnin P, Kubis N, Henrion D, Silvestre JS, Lévy BI. Peripheral postischemic vascular repair is impaired in a murine model of Alzheimer's disease. Angiogenesis. 2018; 21:557-69.

https://doi.org/10.1007/s10456-018-9608-7 PMID:29516292

14. Asllani I, Habeck C, Scarmeas N, Borogovac A, Brown TR, Stern Y. Multivariate and univariate analysis of continuous arterial spin labeling perfusion $\mathrm{MRI}$ in Alzheimer's disease. J Cereb Blood Flow Metab. 2008; 28:725-36.

https://doi.org/10.1038/sj.jcbfm.9600570

PMID:17960142

15. Cruz Hernández JC, Bracko O, Kersbergen CJ, Muse V, Haft-Javaherian M, Berg M, Park L, Vinarcsik LK, Ivasyk I, Rivera DA, Kang Y, Cortes-Canteli M, Peyrounette $\mathrm{M}$, et al. Neutrophil adhesion in brain capillaries reduces cortical blood flow and impairs memory function in Alzheimer's disease mouse models. Nat Neurosci. 2019; 22:413-20. https://doi.org/10.1038/s41593-018-0329-4 PMID:30742116

16. Sojkova J, Beason-Held L, Zhou Y, An Y, Kraut MA, Ye W, Ferrucci L, Mathis CA, Klunk WE, Wong DF, Resnick $\mathrm{SM}$. Longitudinal cerebral blood flow and amyloid deposition: an emerging pattern? J Nucl Med. 2008; 49:1465-71.

https://doi.org/10.2967/jnumed.108.051946

PMID: 18703614

17. Luckhaus C, Flüß MO, Wittsack HJ, Grass-Kapanke B, Jänner $M$, Khalili-Amiri R, Friedrich W, Supprian T, Gaebel W, Mödder U, Cohnen M. Detection of changed regional cerebral blood flow in mild cognitive impairment and early Alzheimer's dementia by perfusion-weighted magnetic resonance imaging. Neuroimage. 2008; 40:495-503.

https://doi.org/10.1016/i.neuroimage.2007.11.053 PMID: $\underline{18207425}$

18. Encinas M, De Juan R, Marcos A, Gil P, Barabash A, Fernández C, De Ugarte C, Cabranes JA. Regional cerebral blood flow assessed with 99mTc-ECD SPET as a marker of progression of mild cognitive impairment to Alzheimer's disease. Eur J Nucl Med Mol Imaging. 2003; 30:1473-80. 
https://doi.org/10.1007/s00259-003-1277-z PMID: 14579086

19. Hirao K, Ohnishi T, Hirata Y, Yamashita F, Mori T, Moriguchi $Y$, Matsuda $H$, Nemoto K, Imabayashi $E$, Yamada M, Iwamoto T, Arima K, Asada T. The prediction of rapid conversion to Alzheimer's disease in mild cognitive impairment using regional cerebral blood flow SPECT. Neuroimage. 2005; 28:1014-21. https://doi.org/10.1016/i.neuroimage.2005.06.066 PMID:16129627

20. Borroni B, Anchisi D, Paghera B, Vicini B, Kerrouche N, Garibotto V, Terzi A, Vignolo LA, Di Luca M, Giubbini R, Padovani A, Perani D. Combined 99mTc-ECD SPECT and neuropsychological studies in $\mathrm{MCl}$ for the assessment of conversion to AD. Neurobiol Aging. 2006; 27:24-31.

https://doi.org/10.1016/j.neurobiolaging.2004.12.010 PMID:16298237

21. Habert MO, Horn JF, Sarazin M, Lotterie JA, Puel M, Onen F, Zanca $M$, Portet F, Touchon J, Verny $M$, Mahieux F, Giron A, Fertil B, Dubois B. Brain perfusion SPECT with an automated quantitative tool can identify prodromal Alzheimer's disease among patients with mild cognitive impairment. Neurobiol Aging. 2011; 32:15-23.

https://doi.org/10.1016/i.neurobiolaging.2009.01.013 PMID:19250707

22. Bell RD, Zlokovic BV. Neurovascular mechanisms and blood-brain barrier disorder in Alzheimer's disease. Acta Neuropathol. 2009; 118:103-13.

https://doi.org/10.1007/s00401-009-0522-3 PMID:19319544

23. Zlokovic BV. Neurovascular pathways to neurodegeneration in Alzheimer's disease and other disorders. Nat Rev Neurosci. 2011; 12:723-38.

https://doi.org/10.1038/nrn3114

PMID:22048062

24. Nation DA, Sweeney MD, Montagne A, Sagare AP, D'Orazio LM, Pachicano M, Sepehrband F, Nelson AR, Buennagel DP, Harrington MG, Benzinger TLS, Fagan $A M$, Ringman JM, et al. Blood-brain barrier breakdown is an early biomarker of human cognitive dysfunction. Nat Med. 2019; 25:270-76.

https://doi.org/10.1038/s41591-018-0297-y

PMID:

25. Sagare AP, Bell RD, Zhao Z, Ma Q, Winkler EA, Ramanathan A, Zlokovic BV. Pericyte loss influences Alzheimer-like neurodegeneration in mice. Nat Commun. 2013; 4:2932. https://doi.org/10.1038/ncomms3932 PMID:24336108

26. Sweeney MD, Sagare AP, Zlokovic BV. Blood-brain barrier breakdown in Alzheimer disease and other neurodegenerative disorders. Nat Rev Neurol. 2018; 14:133-50.

https://doi.org/10.1038/nrneurol.2017.188

PMID:29377008

27. Ryu JK, McLarnon JG. A leaky blood-brain barrier, fibrinogen infiltration and microglial reactivity in inflamed Alzheimer's disease brain. J Cell Mol Med. 2009; 13:2911-25.

https://doi.org/10.1111/i.1582-4934.2008.00434.x PMID: 18657226

28. Lu X, Moeini M, Li B, Lu Y, Damseh R, Pouliot P, Thorin É, Lesage F. A Pilot Study Investigating Changes in Capillary Hemodynamics and Its Modulation by Exercise in the APP-PS1 Alzheimer Mouse Model. Front Neurosci. 2019; 13:1261.

https://doi.org/10.3389/fnins.2019.01261 PMID: 31920472

29. Hong J, Hong SG, Lee J, Park JY, Eriksen JL, Rooney BV, Park Y. Exercise training ameliorates cerebrovascular dysfunction in a murine model of Alzheimer's disease: role of the $\mathrm{P} 2 \mathrm{Y} 2$ receptor and endoplasmic reticulum stress. Am J Physiol Heart Circ Physiol. 2020; 318:H1559-69.

https://doi.org/10.1152/ajpheart.00129.2020

PMID: 32383993

30. Ruitenberg A, den Heijer T, Bakker SL, van Swieten JC, Koudstaal PJ, Hofman A, Breteler MM. Cerebral hypoperfusion and clinical onset of dementia: the Rotterdam Study. Ann Neurol. 2005; 57:789-94.

https://doi.org/10.1002/ana.20493 PMID: 15929050

31. Badji A, Westman E. Cerebrovascular pathology in Alzheimer's disease: Hopes and gaps. Psychiatry Res Neuroimaging. 2020; 306:111184. https://doi.org/10.1016/i.pscychresns.2020.111184 PMID:32950333

32. Iturria-Medina $\mathrm{Y}$, Sotero RC, Toussaint PJ, MateosPérez JM, Evans AC, and Alzheimer's Disease Neuroimaging Initiative. Early role of vascular dysregulation on late-onset Alzheimer's disease based on multifactorial data-driven analysis. Nat Commun. 2016; 7:11934.

https://doi.org/10.1038/ncomms11934 PMID:27327500

33. Love S, Miners JS. Cerebrovascular disease in ageing and Alzheimer's disease. Acta Neuropathol. 2016; 131:645-58. https://doi.org/10.1007/s00401-015-1522-0 PMID:26711459

34. Johnson KA, Lopera F, Jones K, Becker A, Sperling R, Hilson J, Londono J, Siegert I, Arcos M, Moreno S, 
Madrigal L, Ossa J, Pineda N, et al. Presenilin-1associated abnormalities in regional cerebral perfusion. Neurology. 2001; 56:1545-51.

https://doi.org/10.1212/wnl.56.11.1545

PMID:11402113

35. Thambisetty M, Beason-Held L, An Y, Kraut MA, Resnick SM. APOE epsilon4 genotype and longitudinal changes in cerebral blood flow in normal aging. Arch Neurol. 2010; 67:93-98.

https://doi.org/10.1001/archneurol.2009.913

PMID:20065135

36. Montagne A, Nation DA, Sagare AP, Barisano G, Sweeney MD, Chakhoyan A, Pachicano M, Joe E, Nelson AR, D'Orazio LM, Buennagel DP, Harrington MG, Benzinger TLS, et al. APOE4 leads to blood-brain barrier dysfunction predicting cognitive decline. Nature. 2020; 581:71-76.

https://doi.org/10.1038/s41586-020-2247-3

PMID:32376954

37. Lin YF, Smith AV, Aspelund T, Betensky RA, Smoller JW, Gudnason V, Launer $\sqcup$, Blacker D. Genetic overlap between vascular pathologies and Alzheimer's dementia and potential causal mechanisms. Alzheimers Dement. 2019; 15:65-75.

https://doi.org/10.1016/j.jalz.2018.08.002 PMID:30240575

38. d'Uscio LV, He T, Katusic ZS. Expression and Processing of Amyloid Precursor Protein in Vascular Endothelium. Physiology (Bethesda). 2017; 32:20-32. https://doi.org/10.1152/physiol.00021.2016 PMID:27927802

39. Kitazume S, Tachida $Y$, Kato M, Yamaguchi Y, Honda T, Hashimoto Y, Wada Y, Saito T, Iwata N, Saido T, Taniguchi N. Brain endothelial cells produce amyloid $\{\beta\}$ from amyloid precursor protein 770 and preferentially secrete the O-glycosylated form. J Biol Chem. 2010; 285:40097-103.

https://doi.org/10.1074/jbc.M110.144626

PMID:20952385

40. Nortley R, Korte N, Izquierdo P, Hirunpattarasilp C, Mishra A, Jaunmuktane Z, Kyrargyri V, Pfeiffer T, Khennouf L, Madry C, Gong H, Richard-Loendt A, Huang $W$, et al. Amyloid $\beta$ oligomers constrict human capillaries in Alzheimer's disease via signaling to pericytes. Science. 2019; 365:eaav9518.

https://doi.org/10.1126/science.aav9518

PMID: $\underline{31221773}$

41. Price JM, Chi X, Hellermann G, Sutton ET. Physiological levels of beta-amyloid induce cerebral vessel dysfunction and reduce endothelial nitric oxide production. Neurol Res. 2001; 23:506-12.

https://doi.org/10.1179/016164101101198758 PMID: 11474807
42. Thomas T, McLendon C, Sutton ET, Thomas G. Cerebrovascular endothelial dysfunction mediated by ß-amyloid. Neuroreport. 1997; 8:1387-91. https://doi.org/10.1097/00001756-199704140-00014 PMID: $\underline{9172141}$

43. Niwa K, Porter VA, Kazama K, Cornfield D, Carlson GA, ladecola $\mathrm{C}$. A beta-peptides enhance vasoconstriction in cerebral circulation. Am J Physiol Heart Circ Physiol. 2001; 281:H2417-24.

https://doi.org/10.1152/ajpheart.2001.281.6.H2417 PMID:11709407

44. Thomas $T$, Thomas G, McLendon C, Sutton T, Mullan $M$. beta-Amyloid-mediated vasoactivity and vascular endothelial damage. Nature. 1996; 380:168-71.

https://doi.org/10.1038/380168a0

PMID:8600393

45. Crawford F, Suo ZM, Fang CH, Mullan $M$. Characteristics of the in vitro vasoactivity of $\beta$-amyloid peptides. Exp Neurol. 1998; 150:159-68.

https://doi.org/10.1006/exnr.1997.6743 PMID:9514824

46. Paris D, Humphrey J, Quadros A, Patel N, Crescentini $\mathrm{R}$, Crawford F, Mullan M. Vasoactive effects of $A$ beta in isolated human cerebrovessels and in a transgenic mouse model of Alzheimer's disease: role of inflammation. Neurol Res. 2003; 25:642-51.

https://doi.org/10.1179/016164103101201940 PMID:14503019

47. Haase N, Herse F, Spallek B, Haase H, Morano I, Qadri F, Szijarto IA, Rohm I, Yilmaz A, Warrington JP, Ryan MJ, Gollasch M, Muller DN, et al. Amyloid- $\beta$ peptides activate $\alpha 1$-adrenergic cardiovascular receptors. Hypertension. 2013; 62:966-72.

https://doi.org/10.1161/HYPERTENSIONAHA.113.01348 PMID:24001898

48. Suo Z, Humphrey J, Kundtz A, Sethi F, Placzek A, Crawford F, Mullan M. Soluble Alzheimers betaamyloid constricts the cerebral vasculature in vivo. Neurosci Lett. 1998; 257:77-80.

https://doi.org/10.1016/s0304-3940(98)00814-3 PMID: 9865931

49. Deane R, Du Yan S, Submamaryan RK, LaRue B, Jovanovic S, Hogg E, Welch D, Manness L, Lin C, Yu J, Zhu H, Ghiso J, Frangione B, et al. RAGE mediates amyloid-beta peptide transport across the bloodbrain barrier and accumulation in brain. Nat Med. 2003; 9:907-13.

https://doi.org/10.1038/nm890 PMID: 12808450

50. Dietrich HH, Xiang C, Han BH, Zipfel GJ, Holtzman DM. Soluble amyloid-beta, effect on cerebral arteriolar regulation and vascular cells. Mol Neurodegener. 2010; 5:15. 
https://doi.org/10.1186/1750-1326-5-15 PMID:20388225

51. Park L, Zhou P, Koizumi K, El Jamal S, Previti ML, Van Nostrand WE, Carlson G, ladecola C. Brain and circulating levels of A $\beta 1-40$ differentially contribute to vasomotor dysfunction in the mouse brain. Stroke. 2013; 44:198-204. https://doi.org/10.1161/STROKEAHA.112.670976 PMID:23204056

52. Koster KP, Thomas R, Morris AWJ, Tai LM. Epidermal growth factor prevents oligomeric amyloid- $\beta$ induced angiogenesis deficits in vitro. J Cereb Blood Flow Metab. 2016; 36:1865-71. https://doi.org/10.1177/0271678X16669956 PMID:27634936

53. Niwa K, Carlson GA, ladecola C. Exogenous A $B 1-40$ reproduces cerebrovascular alterations resulting from amyloid precursor protein overexpression in mice. J Cereb Blood Flow Metab. 2000; 20:1659-68. https://doi.org/10.1097/00004647-200012000-00005 PMID:11129782

54. Koizumi K, Wang G, Park L. Endothelial dysfunction and amyloid-b-induced neurovascular alterations. Cell Mol Neurobiol. 2016; 36:155-65. https://doi.org/10.1007/s10571-015-0256-9 PMID:26328781

55. Koizumi K, Hattori Y, Ahn SJ, Buendia I, Ciacciarelli A, Uekawa K, Wang G, Hiller A, Zhao L, Voss HU, Paul SM, Schaffer C, Park L, ladecola C. Apoe4 disrupts neurovascular regulation and undermines white matter integrity and cognitive function. Nat Commun. 2018; 9:3816.

https://doi.org/10.1038/s41467-018-06301-2 PMID:30232327

56. Donner L, Fälker K, Gremer L, Klinker S, Pagani G, Ljungberg LU, Lothmann K, Rizzi F, Schaller M, Gohlke $H$, Willbold D, Grenegard M, Elvers M. Platelets contribute to amyloid- $\beta$ aggregation in cerebral vessels through integrin $\alpha$ llb $\beta 3$-induced outside-in signaling and clusterin release. Sci Signal. 2016; 9:ra52. https://doi.org/10.1126/scisignal.aaf6240 PMID:27221710

57. Bennett RE, Robbins $A B, H u$ M, Cao X, Betensky RA, Clark T, Das S, Hyman BT. Tau induces blood vessel abnormalities and angiogenesis-related gene expression in P301L transgenic mice and human Alzheimer's disease. Proc Natl Acad Sci U S A. 2018; 115:E1289-98.

https://doi.org/10.1073/pnas.1710329115 PMID:29358399

58. Park L, Hochrainer K, Hattori Y, Ahn SJ, Anfray A, Wang G, Uekawa K, Seo J, Palfini V, Blanco I, Acosta
D, Eliezer D, Zhou P, et al. Tau induces PSD95neuronal NOS uncoupling and neurovascular dysfunction independent of neurodegeneration. Nat Neurosci. 2020; 23:1079-89.

https://doi.org/10.1038/s41593-020-0686-7

PMID:32778793

59. Farkas E, Luiten PGM, Bari F. Permanent, bilateral common carotid artery occlusion in the rat: a model for chronic cerebral hypoperfusion-related neurodegenerative diseases. Brain Res Rev. 2007; 54:162-80.

https://doi.org/10.1016/i.brainresrev.2007.01.003 PMID:17296232

60. Li S, Wang W, Wang C, Tang YY. Possible involvement of NO/NOS signaling in hippocampal amyloid-beta production induced by transient focal cerebral ischemia in aged rats. Neurosci Lett. 2010; 470:106-10. https://doi.org/10.1016/i.neulet.2009.12.064 PMID:20043977

61. de la Torre JC, Mussivand T. Can disturbed brain microcirculation cause Alzheimer's disease? Neurol Res. 1993; 15:146-53.

https://doi.org/10.1080/01616412.1993.11740127 PMID:8103579

62. Sun X, He G, Qing H, Zhou W, Dobie F, Cai F, Staufenbiel M, Huang LE, Song W. Hypoxia facilitates Alzheimer's disease pathogenesis by up-regulating BACE1 gene expression. Proc Natl Acad Sci U S A. 2006; 103:18727-32.

https://doi.org/10.1073/pnas.0606298103

PMID:17121991

63. Zhang X, Zhou K, Wang R, Cui J, Lipton SA, Liao FF, Xu $\mathrm{H}$, Zhang YW. Hypoxia-inducible factor 1alpha (HIF1alpha)-mediated hypoxia increases BACE1 expression and beta-amyloid generation. J Biol Chem. 2007; 282:10873-80.

https://doi.org/10.1074/ibc.M608856200 PMID: 17303576

64. Sweeney MD, Sagare AP, Zlokovic BV. Cerebrospinal fluid biomarkers of neurovascular dysfunction in mild dementia and Alzheimer's disease. J Cereb Blood Flow Metab. 2015; 35:1055-68.

https://doi.org/10.1038/jcbfm.2015.76 PMID:25899298

65. Gupta A, ladecola C. Impaired A $\beta$ clearance: a potential link between atherosclerosis and Alzheimer's disease. Front Aging Neurosci. 2015; 7:115. https://doi.org/10.3389/fnagi.2015.00115 PMID:26136682

66. Cao Y, Xu H, Zhu Y, Shi MJ, Wei L, Zhang J, Cheng S, Shi $Y$, Tong $H$, Kang $L$, Lu L, Luo $H$, Yang $X$, et al. ADAMTS13 maintains cerebrovascular integrity to 
ameliorate Alzheimer-like pathology. PLoS Biol. 2019; 17:e3000313.

https://doi.org/10.1371/journal.pbio.3000313 PMID:31185010

67. Albrecht $D$, Isenberg AL, Stradford J, Monreal T, Sagare A, Pachicano M, Sweeney M, Toga A, Zlokovic $B$, Chui $H$, Joe $E$, Schneider $L$, Conti $P$, et al. Associations between Vascular Function and Tau PET Are Associated with Global Cognition and Amyloid. J Neurosci. 2020; 40:8573-86.

https://doi.org/10.1523/JNEUROSCI.1230-20.2020 PMID: $\underline{3046556}$

68. Laing KK, Simoes S, Baena-Caldas GP, Lao PJ, Kothiya $M$, Igwe KC, Chesebro AG, Houck AL, Pedraza L, Hernández Al, Li J, Zimmerman ME, Luchsinger JA, et al, and Alzheimer's Disease Neuroimaging Initiative. Cerebrovascular disease promotes tau pathology in Alzheimer's disease. Brain Commun. 2020; 2:fcaa132. https://doi.org/10.1093/braincomms/fcaa132 PMID:33215083

69. Zhang F, Gannon M, Chen Y, Yan S, Zhang S, Feng W, Tao J, Sha B, Liu Z, Saito T, Saido T, Keene CD, Jiao K, et al. $\beta$-amyloid redirects norepinephrine signaling to activate the pathogenic GSK3 $\beta /$ tau cascade. Sci TransI Med. 2020; 12:eaay6931.

https://doi.org/10.1126/scitranslmed.aay6931 PMID:31941827

70. Karczewski P, Hempel P, Bimmler M. Role of alpha1adrenergic receptor antibodies in Alzheimer's disease. Front Biosci (Landmark Ed). 2018; 23:2082-89.

https://doi.org/10.2741/4691

PMID:29772547

71. Stracke S, Lange S, Bornmann S, Kock H, Schulze L, KlingerKönig J, Böhm S, Vogelgesang A, von Podewils F, Föel A, Gross S, Wenzel K, Wallukat G, et al. Immunoadsorption for Treatment of Patients with Suspected Alzheimer Dementia and Agonistic Autoantibodies against Alpha1aAdrenoceptor-Rationale and Design of the IMAD Pilot Study. J Clin Med. 2020; 9:1919.

https://doi.org/10.3390/jcm9061919

PMID:32575439

72. Ruffolo RR Jr, Nichols AJ, Stadel JM, Hieble JP. Pharmacologic and therapeutic applications of alpha 2-adrenoceptor subtypes. Annu Rev Pharmacol Toxicol. 1993; 33:243-79.

https://doi.org/10.1146/annurev.pa.33.040193.001331 PMID: 8098595

73. Handy DE, Johns C, Bresnahan MR, Tavares A, Bursztyn M, Gavras H. Expression of alpha2adrenergic receptors in normal and atherosclerotic rabbit aorta. Hypertension. 1998; 32:311-17.

https://doi.org/10.1161/01.hyp.32.2.311 PMID: 9719060
74. Roberts RE. Role of the extracellular signal-regulated kinase (Erk) signal transduction cascade in alpha(2) adrenoceptor-mediated vasoconstriction in porcine palmar lateral vein. Br J Pharmacol. 2001; 133:859-66. https://doi.org/10.1038/sj.bjp.0704149 PMID:11454659

75. Zhang JF, Wiseman S, Valdés-Hernández MC, Doubal FN, Dhillon B, Wu YC, Wardlaw JM. The Application of Optical Coherence Tomography Angiography in Cerebral Small Vessel Disease, Ischemic Stroke, and Dementia: A Systematic Review. Front Neurol. 2020; 11:1009.

https://doi.org/10.3389/fneur.2020.01009 PMID:33013667

76. Whittington RA, Virág L, Gratuze M, Petry FR, Noël A, Poitras I, Truchetti G, Marcouiller F, Papon MA, El Khoury N, Wong K, Bretteville A, Morin F, et al. Dexmedetomidine increases tau phosphorylation under normothermic conditions in vivo and in vitro. Neurobiol Aging. 2015; 36:2414-28.

https://doi.org/10.1016/i.neurobiolaging.2015.05.002 PMID:26058840

77. Davel AP, Kawamoto EM, Scavone C, Vassallo DV, Rossoni LV. Changes in vascular reactivity following administration of isoproterenol for 1 week: a role for endothelial modulation. $\mathrm{Br} J$ Pharmacol. 2006; 148:629-39.

https://doi.org/10.1038/sj.bjp.0706749

PMID:16702995

78. Davel AP, Brum PC, Rossoni LV. Isoproterenol induces vascular oxidative stress and endothelial dysfunction via a Gi $\alpha$-coupled $\beta 2$-adrenoceptor signaling pathway. PLoS One. 2014; 9:e91877. https://doi.org/10.1371/journal.pone.0091877 PMID:24622771

79. Wang D, Govindaiah G, Liu R, De Arcangelis V, Cox CL, Xiang YK. Binding of amyloid beta peptide to beta2 adrenergic receptor induces PKA-dependent AMPA receptor hyperactivity. FASEB J. 2010; 24:3511-21. https://doi.org/10.1096/fi.10-156661 PMID:20395454

80. Wang D, Fu Q, Zhou Y, Xu B, Shi Q, Igwe B, Matt L, Hell JW, Wisely EV, Oddo $S$, Xiang YK. $\beta 2$ adrenergic receptor, protein kinase $\mathrm{A}$ (PKA) and c-Jun $\mathrm{N}$-terminal kinase (JNK) signaling pathways mediate tau pathology in Alzheimer disease models. J Biol Chem. 2013; 288:10298-307.

https://doi.org/10.1074/ibc.M112.415141

PMID:23430246

81. Wisely EV, Xiang YK, Oddo S. Genetic suppression of $\beta 2$-adrenergic receptors ameliorates tau pathology in a mouse model of tauopathies. Hum Mol Genet. 2014; 23:4024-34. 
https://doi.org/10.1093/hmg/ddu116

PMID:24626633

82. Guimarães S, Moura D. Vascular adrenoceptors: an update. Pharmacol Rev. 2001; 53:319-56.

PMID:11356987

83. Tournissac M, Vu TM, Vrabic N, Hozer C, Tremblay C, Mélançon K, Planel E, Pifferi F, Calon F. Repurposing beta-3 adrenergic receptor agonists for Alzheimer's disease: beneficial effects in a mouse model. Alzheimers Res Ther. 2021; 13:103. https://doi.org/10.1186/s13195-021-00842-3 PMID:34020681

84. Gibbs ME, Gibbs Z, Hertz L. Rescue of Abeta(1-42)induced memory impairment in day-old chick by facilitation of astrocytic oxidative metabolism: implications for Alzheimer's disease. J Neurochem. 2009 (Suppl 1); 109:230-36.

https://doi.org/10.1111/i.1471-4159.2009.05800.x PMID:19393032

85. Ardestani PM, Evans AK, Yi B, Nguyen T, Coutellier L, Shamloo M. Modulation of neuroinflammation and pathology in the 5XFAD mouse model of Alzheimer's disease using a biased and selective beta- 1 adrenergic receptor partial agonist. Neuropharmacology. 2017; 116:371-86.

https://doi.org/10.1016/j.neuropharm.2017.01.010 PMID:28089846

86. Coutellier L, Ardestani PM, Shamloo M. $\beta 1$ adrenergic receptor activation enhances memory in Alzheimer's disease model. Ann Clin Transl Neurol. 2014; 1:348-60.

https://doi.org/10.1002/acn3.57

PMID:24883337

87. Evans AK, Ardestani PM, Yi B, Park HH, Lam RK, Shamloo M. Beta-adrenergic receptor antagonism is proinflammatory and exacerbates neuroinflammation in a mouse model of Alzheimer's Disease. Neurobiol Dis. 2020; $146: 105089$.

https://doi.org/10.1016/j.nbd.2020.105089

PMID:32971233

88. Winblad B, Bonura ML, Rossini BM, Battaglia A. Nicergoline in the treatment of mild-to-moderate Alzheimer's disease. Clin Drug Investig. 2001; 21:621-32.

https://doi.org/10.2165/00044011-200121090-00004

89. Deane R, Wu Z, Sagare A, Davis J, Du Yan S, Hamm K, Xu F, Parisi M, LaRue B, Hu HW, Spijkers P, Guo H, Song $X$, et al. LRP/amyloid beta-peptide interaction mediates differential brain efflux of Abeta isoforms. Neuron. 2004; 43:333-44.

https://doi.org/10.1016/i.neuron.2004.07.017 PMID:15294142
90. Deane R, Wu Z, Zlokovic BV. RAGE (yin) versus LRP (yang) balance regulates Alzheimer amyloid betapeptide clearance through transport across the blood-brain barrier. Stroke. 2004 (Suppl 1); 35:262831.

https://doi.org/10.1161/01.STR.0000143452.85382.d1 PMID:15459432

91. Eisele YS, Obermüller U, Heilbronner G, Baumann F, Kaeser SA, Wolburg H, Walker LC, Staufenbiel M, Heikenwalder $M$, Jucker $M$. Peripherally applied Abeta-containing inoculates induce cerebral betaamyloidosis. Science. 2010; 330:980-82.

https://doi.org/10.1126/science.1194516 PMID:20966215

92. Kumar-Singh S, Pirici D, McGowan E, Serneels $S$, Ceuterick C, Hardy J, Duff K, Dickson D, Van Broeckhoven C. Dense-core plaques in Tg2576 and PSAPP mouse models of Alzheimer's disease are centered on vessel walls. Am J Pathol. 2005; 167:527-43.

https://doi.org/10.1016/S0002-9440(10)62995-1 PMID:16049337

93. Weller RO, Subash M, Preston SD, Mazanti I, Carare RO. Perivascular drainage of amyloid-beta peptides from the brain and its failure in cerebral amyloid angiopathy and Alzheimer's disease. Brain Pathol. 2008; 18:253-66.

https://doi.org/10.1111/i.1750-3639.2008.00133.x PMID: 18363936

94. Sagare AP, Bell RD, Zlokovic BV. Neurovascular dysfunction and faulty amyloid $\beta$-peptide clearance in Alzheimer disease. Cold Spring Harb Perspect Med. 2012; 2:a011452.

https://doi.org/10.1101/cshperspect.a011452 PMID:23028132

95. Ujiie M, Dickstein DL, Carlow DA, Jefferies WA. Blood-brain barrier permeability precedes senile plaque formation in an Alzheimer disease model. Microcirculation. 2003; 10:463-470. https://doi.org/10.1038/sj.mn.7800212 PMID:14745459

96. Rohn TT. Proteolytic cleavage of apolipoprotein E4 as the keystone for the heightened risk associated with Alzheimer's disease. Int J Mol Sci. 2013; 14:1490822.

https://doi.org/10.3390/ijms140714908 PMID:23867607

97. Shi H, Koronyo $\mathrm{Y}$, Fuchs DT, Sheyn J, Wawrowsky K, Lahiri S, Black KL, Koronyo-Hamaoui M. Retinal capillary degeneration and blood-retinal barrier disruption in murine models of Alzheimer's disease. Acta Neuropathol Commun. 2020; 8:202. 
https://doi.org/10.1186/s40478-020-01076-4

PMID:33228786

98. Kotliar K, Hauser C, Ortner M, Muggenthaler C, Diehl-Schmid J, Angermann S, Hapfelmeier A, Schmaderer C, Grimmer T. Altered neurovascular coupling as measured by optical imaging: a biomarker for Alzheimer's disease. Sci Rep. 2017; 7:12906. https://doi.org/10.1038/s41598-017-13349-5 PMID:29018233

99. Golzan SM, Goozee K, Georgevsky D, Avolio A, Chatterjee P, Shen K, Gupta V, Chung R, Savage G, Orr CF, Martins RN, Graham SL. Retinal vascular and structural changes are associated with amyloid burden in the elderly: ophthalmic biomarkers of preclinical Alzheimer's disease. Alzheimers Res Ther. 2017; 9:13.

https://doi.org/10.1186/s13195-017-0239-9

PMID:28253913

100. den Haan J, van de Kreeke JA, van Berckel BN, Barkhof F, Teunissen CE, Scheltens P, Verbraak FD, Bouwman $\mathrm{FH}$. Is retinal vasculature a biomarker in amyloid proven Alzheimer's disease? Alzheimers Dement (Amst). 2019; 11:383-91.

https://doi.org/10.1016/j.dadm.2019.03.006 PMID:31193094

101. Chua J, Hu Q, Ke M, Tan B, Hong J, Yao X, Hilal S, Venketasubramanian N, Garhöfer G, Cheung CY, Wong TY, Chen CL, Schmetterer L. Retinal microvasculature dysfunction is associated with Alzheimer's disease and mild cognitive impairment. Alzheimers Res Ther. 2020; 12:161. https://doi.org/10.1186/s13195-020-00724-0 PMID:33276820

102. Salobrar-Garcia E, Méndez-Hernández C, Hoz R, Ramírez Al, López-Cuenca I, Fernández-Albarral JA, Rojas P, Wang S, García-Feijoo J, Gil P, Salazar JJ, Ramírez JM. Ocular Vascular Changes in Mild Alzheimer's Disease Patients: Foveal Avascular Zone, Choroidal Thickness, and ONH Hemoglobin Analysis. J Pers Med. 2020; 10:231. https://doi.org/10.3390/ipm10040231 PMID:33203157

103. Wu SZ, Masurkar AV, Balcer LJ. Afferent and Efferent Visual Markers of Alzheimer's Disease: A Review and Update in Early Stage Disease. Front Aging Neurosci. 2020; $12: 572337$.

https://doi.org/10.3389/fnagi.2020.572337 PMID:33061906

104. Asanad S, Mohammed I, Sadun AA, Saeedi OJ. OCTA in neurodegenerative optic neuropathies: emerging biomarkers at the eye-brain interface. Ther Adv Ophthalmol. 2020; 12:2515841420950508. https://doi.org/10.1177/2515841420950508 PMID:32923939

105. Kelly $\mathrm{P}, \mathrm{McClean} \mathrm{PL}$, Ackermann M, Konerding MA, Hölscher C, Mitchell CA. Restoration of cerebral and systemic microvascular architecture in APP/PS1 transgenic mice following treatment with Liraglutide $^{\mathrm{TM}}$. Microcirculation. 2015; 22:133-45.

https://doi.org/10.1111/micc.12186 PMID:25556713

106. Tachibana M, Yamazaki Y, Liu CC, Bu G, Kanekiyo T. Pericyte implantation in the brain enhances cerebral blood flow and reduces amyloid- $\beta$ pathology in amyloid model mice. Exp Neurol. 2018; 300:13-21. https://doi.org/10.1016/i.expneurol.2017.10.023 PMID:29106980

107. Im JJ, Jeong HS, Park JS, Yang Y, Na SH, Oh JK, Chung YA, Song IU. Changes in Regional Cerebral Perfusion after Nicergoline Treatment in Early Alzheimer's Disease: A Pilot Study. Dement Neurocogn Disord. 2017; 16:104-09. https://doi.org/10.12779/dnd.2017.16.4.104 PMID: $\underline{30906380}$ 